\title{
21. UPPER QUATERNARY DIATOMS IN THE AMAZON FAN OF THE WESTERN ATLANTIC ${ }^{1}$
}

\author{
Naja Mikkelsen ${ }^{2}$
}

\begin{abstract}
Diatoms are rare in the upper Pleistocene/Holocene sediments recovered during Ocean Drilling Program (ODP) Leg 155 from the Amazon Fan. The diatom assemblages are generally characterized by a few solution-resistant species of marine origin and are only found in hemipelagic sediments younger than $12 \mathrm{ka}$. Most assemblages have a minor contribution of freshwater diatoms (average 10\%-30\%), reflecting the influence of discharge from the Amazon River. The highest freshwater diatom abundance is off the flank of the fan (75\%), and it is likely a result of the northward sweep of the Amazon freshwater plume. The high production of diatom frustules reported from the estuarine area of the Amazon River is not reflected in Amazon Fan sediments due to rapid dissolution and the recycling of opaline diatom frustules. Diatoms are absent from glacial-aged Amazon Fan deposits. Glacial sediments are barren of diatoms and characterized by terrigenous material funneled directly into the deep sea through the Amazon Submarine Canyon during low sea-level stands. Diatoms are similarly rare in upper Quaternary sequences of the open ocean environment of the Ceara Rise region. In contrast to the western equatorial Atlantic, diatoms are common in the eastern equatorial Atlantic. The general low abundance of diatoms in the Amazon Fan region is therefore controlled by post-depositional dissolution superimposed on a cross-basinal productivity gradient.
\end{abstract}

\section{INTRODUCTION}

The Amazon estuary is the largest single supplier of dissolved silica to the world's oceans. The Amazon River represents $\sim 18 \%$ of the total global runoff and contributes $\sim 40 \%$ of the dissolved silica brought into the Atlantic Ocean. The coastal waters of the Amazon estuary contain high concentrations of diatom and dinoflagellate floras, and diatom frustules are the prime component of suspended matter in the brackish water plume off the Amazon River (Wood, 1966). The distribution of modern diatoms in the region of the Amazon delta indicates three distinct diatom floras. Floras north and south of the Amazon Canyon are dominated by marine species, whereas a distinct community dominated by freshwater diatoms is found in the estuary itself (Wood, 1966). Empty marine diatom frustules have been observed more than $300 \mathrm{~km}$ upstream in the Amazon River (Gessner and Simonsen, 1967), illustrating the very dynamic nature of the Amazon River system and the local marine environment.

Milliman and Boyle (1975) have calculated that 15 million tons of opaline diatom frustules are produced annually within the Amazon estuary. Most of this biogenic silica $(75 \%-88 \%)$ nevertheless dissolves in the water column and/or at the sediment/water interface (DeMaster et al., 1983; Tréguer et al., 1995). Accumulation of biogenic silica on the shelf is therefore restricted and only equivalent to $4 \%$ of the river-borne silica supply (DeMaster et al., 1983).

This paper represents a preliminary study of the rarely occurring diatoms in the Amazon Fan sediments recovered during Ocean Drilling Program (ODP) Leg 155. The distribution and preservation of marine and freshwater diatoms in the sedimentary record are examined with the aim of outlining the temporal and spatial variation in the composition of the diatom assemblages.

${ }^{1}$ Flood, R.D., Piper, D.J.W., Klaus, A., and Peterson, L.C. (Eds.), 1997. Proc. ODP, Sci. Results, 155: College Station, TX (Ocean Drilling Program).

${ }^{2}$ Geological Survey of Denmark and Greenland, Thoravej 8, DK-2400 Copenhagen NV, Denmark.nm@geus.dk

\section{MATERIAL AND METHODS}

The distribution of marine and freshwater diatoms in relation to modern Amazon Fan sedimentation was studied by analyzing mudline and core top samples from the 17 sites recovered during Leg 155 (Fig. 1). To study temporal variation in diatom abundance and assemblages, samples were taken from a wide range of depths at each of the 17 sites (Flood, Piper, Klaus, et al., 1995). The drilled depths of the Leg 155 holes vary from 15 to $430 \mathrm{~m}$, but due to the very high sedimentation rates, the age of the oldest sediments recovered is less than 1475 ka (Flood, Piper, Klaus, et al., 1995). The recovered sections are characterized by hemipelagic carbonate oozes of interglacial origin alternating with glacial sediments and turbidites. The glacial sediments reflect significant terrigenous input that was funneled across the shelf to the deep-sea fan through the Amazon Canyon during low sea-level stands.

The late glacial Holocene occurrence of diatoms was examined in Hole 931A, which was drilled on the central fan, Holes 942A and 942C drilled off the fan, and compared with assemblages from the open ocean environment of the Ceara Rise (ODP Site 927; Table 1; Fig. 1).

Samples were processed aboard the JOIDES Resolution by placing $0.5 \mathrm{~g}$ of material in a $100-\mathrm{mL}$ beaker. Ten percent $\mathrm{HCl}$ and subsequently $10 \% \mathrm{H}_{2} \mathrm{O}_{2}$ were added, and the sample was gently heated until the liquid became light yellow. The beaker was then half filled with distilled water and left to settle for $4 \mathrm{hr}$. The supernatant was decanted off and the sample repeatedly washed until the liquid reached a $\mathrm{pH}$ of 6 . Strewn slides of acid-cleaned material were mounted on glass slides with Hyrax mounting medium.

Shore-based preparation of additional samples followed the method of Barron (1985). Approximately $0.1 \mathrm{~g}$ of sediment was placed in a centrifuge tube and $10 \% \mathrm{HCl}$ added followed by $10 \% \mathrm{H}_{2} \mathrm{O}_{2}$. The tubes were gently heated until the liquid became light yellow. Distilled water was added, and the samples were centrifuged at $2000 \mathrm{rpm}$ for $4 \mathrm{~min}$. This process of adding clean distilled water and centrifug- 
Figure 1. Map showing the Amazon Fan and Ceara Rise region with the sites used in this study.

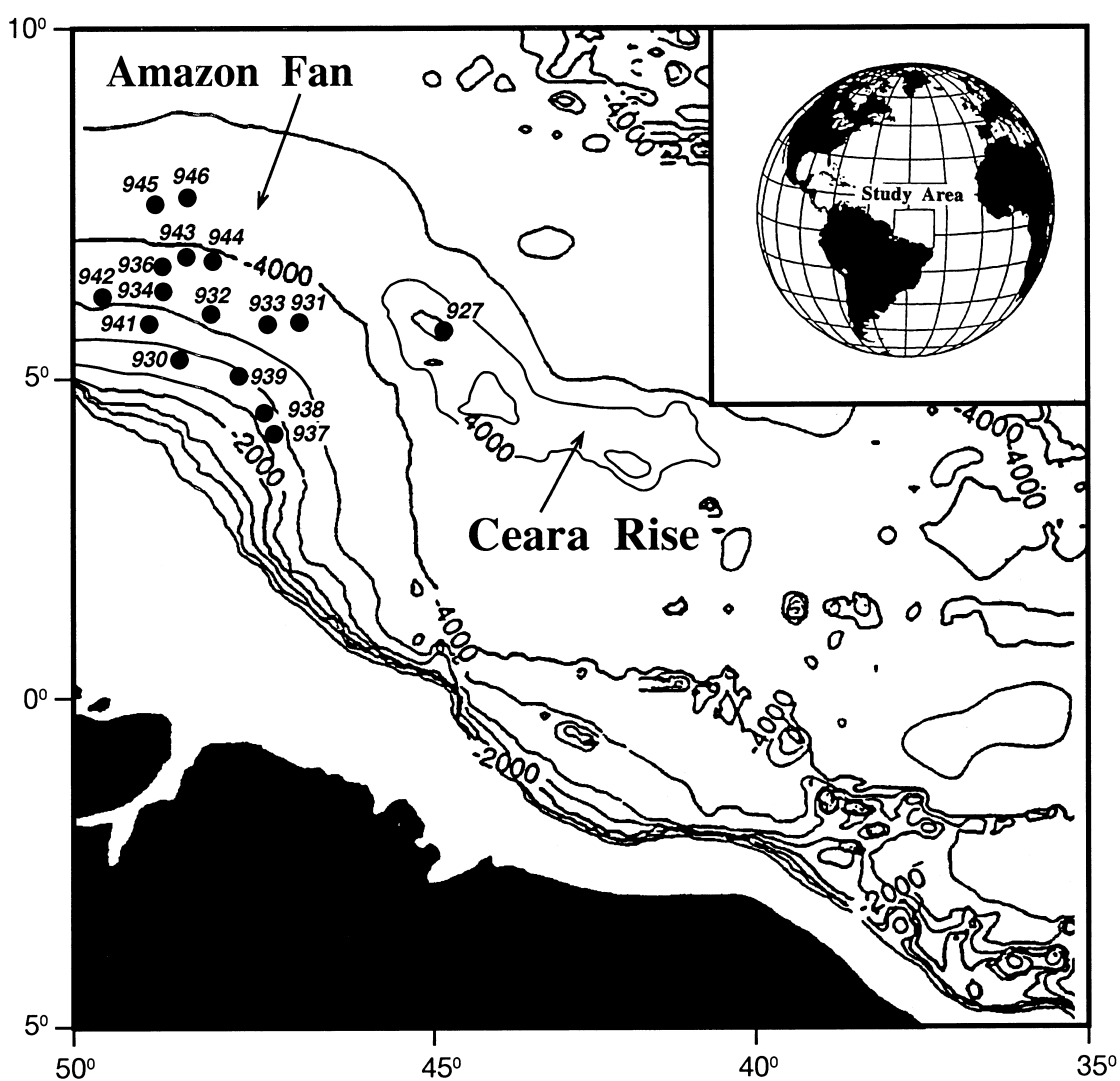

ing was repeated until the suspension $\mathrm{pH}$ was neutralized. Smear slides were prepared by transferring the suspended material with a disposable pipette to a $22 \mathrm{~mm} \times 40 \mathrm{~mm}$ coverslip, which was dried on a hot plate and mounted with Naphrax on a $22 \mathrm{~mm} \times 75 \mathrm{~mm}$ glass slide.

Assessment of the overall abundance of diatoms was semiquantitative. Abundance was recorded as the coverage of diatom valves on the slide surface relative to other particles (in percent). The abundance of diatoms was listed as absent $(-)$, trace $(\mathrm{TR},<1 \%)$, rare $(\mathrm{R}$, $<5 \%$ ), few (F, 5\%-30\%), common (C, 30\%-60\%), and abundant (A, $>60 \%)$. Diatom preservation was noted as good $(\mathrm{G})$ when fine structures of the valves were preserved and weakly silicified forms were present in the assemblage; moderate (M) when the assemblage showed moderate breakage and light dissolution; and poor $(\mathrm{P})$ when more than $30 \%$ of all valves were broken and the assemblage was affected by partial dissolution.

\section{RESULTS}

The high production of diatoms in the surface waters of the Amazon estuarine area as described by Milliman and Boyle (1975) is not reflected in the sediments of the Amazon Fan. Diatoms are, in general, rare and poorly preserved, except for the surface samples.

\section{Surface Distribution}

The abundance of diatoms in surface sediment and mudline samples of the Amazon Fan shows an overall random distribution, apart from a moderately lower abundance in the upper fan sites as compared with the middle fan sites (Fig. 2A). The marine components of the diatom assemblages are dominated by solution-resistant, warmwater species such as Azpeitia nodulifera and Thalassiosira oestrupii
(Table 2). Freshwater diatoms are mainly Aulacosira granulata and Cyclotella striata. Benthic diatoms are also present but in low abundances. The overall preservation of diatom assemblages in the surface samples is slightly better in the deeper sites of the fan (Sites 945 and 946; water depths of 4136 and $4100 \mathrm{~m}$, respectively), as compared with the more shallow sites (Sites 937 and 938; water depths of 2760 and $2804 \mathrm{~m}$, respectively), suggesting a depth-related preservation of siliceous microfossils.

Freshwater diatoms are consistently present in surface sediments of the Amazon Fan. Freshwater species constitute, on average, 10\%$30 \%$ of the assemblage (Fig. 2B), but may be as high as $75 \%$ in sediments recovered from Site 942 off the western flank of the fan. Because diatom productivity of the freshwater genus Aulacosira, in particular, is high in large low-latitude rivers (Gasse et al., 1989; Pokras and Ruddiman, 1989), a high abundance of freshwater diatoms in the surface sediments of the Amazon Fan should reflect the course of the freshwater plume of the Amazon River. Similarly, changes between phases of increased and decreased river influx during humid and dry episodes on the continent should be reflected in older sediments by higher and lower abundances of freshwater diatoms. However, due to the general lack of diatoms in pre-Holocene Amazon Fan sediments, no changes in continental humidity are reflected in the fan diatomrecords. On the other hand, the high abundance of freshwater diatoms in the surface sediments in Site 942, on the fan flanks, is very likely a result of a northward deflection of the Amazon freshwater plume (Fig. 2B) caused by a change in the prevailing ocean currents.

\section{Interglacial-Glacial Distribution}

Of all sites, Site 942 off the main fan provides the best diatom record. Diatoms are relatively abundant in the youngest Holocene section, but decrease progressively in abundance through the middle part of isotope Stage 1 (Fig. 3). The continuous diatom record ends 
Table 1. The occurrence of diatoms, siliceous sponge spicules, and radiolarians in upper Quaternary samples of Holes 942C, 942A, and 931A from Leg 155, and the composite section of Site 927 of the Ceara Rise (Leg 154).

\begin{tabular}{|c|c|c|c|c|}
\hline $\begin{array}{l}\text { Core, section, } \\
\text { interval }(\mathrm{cm})\end{array}$ & $\begin{array}{l}\text { Depth } \\
\text { (mbsf) }\end{array}$ & $\begin{array}{c}\text { Diatom } \\
\text { abundance }\end{array}$ & Spicules & Radiolarians \\
\hline \multicolumn{5}{|l|}{$155-942 \mathrm{C}-$} \\
\hline $1 \mathrm{H}, \mathrm{ML}$ & 0.00 & $\mathrm{C}$ & - & - \\
\hline $1 \mathrm{H}-1,19-20$ & 0.19 & $\mathrm{~F}$ & + & + \\
\hline $1 \mathrm{H}-1,21-22$ & 0.21 & $\mathrm{R}$ & + & + \\
\hline $1 \mathrm{H}-1,22-23$ & 0.22 & TR-R & + & + \\
\hline $1 \mathrm{H}-1,24-25$ & 0.24 & $\mathrm{TR}-\mathrm{R}$ & + & + \\
\hline $1 \mathrm{H}-1,26-27$ & 0.26 & $\mathrm{R}-\mathrm{F}$ & + & + \\
\hline $1 \mathrm{H}-1,28-29$ & 0.28 & $\mathrm{TR}-\mathrm{R}$ & + & - \\
\hline $1 \mathrm{H}-1,32-33$ & 0.32 & $\mathrm{R}-\mathrm{F}$ & + & + \\
\hline $1 \mathrm{H}-1,34-35$ & 0.34 & $\mathrm{R}-\mathrm{F}$ & + & + \\
\hline $1 \mathrm{H}-1,35-36$ & 0.35 & $\mathrm{R}-\mathrm{F}$ & + & + \\
\hline $1 \mathrm{H}-1,37-38$ & 0.37 & $\mathrm{~F}$ & + & + \\
\hline $1 \mathrm{H}-1,38-39$ & 0.38 & $\mathrm{~F}$ & + & + \\
\hline $1 \mathrm{H}-1,40-41$ & 0.40 & $\mathrm{~F}$ & + & + \\
\hline $1 \mathrm{H}-1,41-42$ & 0.41 & $\mathrm{R}$ & + & - \\
\hline $1 \mathrm{H}-1,43-44$ & 0.43 & $\mathrm{R}-\mathrm{F}$ & + & + \\
\hline $1 \mathrm{H}-1,45-46$ & 0.45 & $\mathrm{R}$ & + & + \\
\hline $1 \mathrm{H}-1,46-47$ & 0.46 & TR & + & + \\
\hline $1 \mathrm{H}-1,48-49$ & 0.48 & TR & + & - \\
\hline $1 \mathrm{H}-1,49-50$ & 0.49 & TR & + & - \\
\hline $1 \mathrm{H}-1,50-51$ & 0.50 & - & + & - \\
\hline $1 \mathrm{H}-1,52-53$ & 0.52 & - & + & - \\
\hline $1 \mathrm{H}-1,54-55$ & 0.54 & - & + & - \\
\hline $1 \mathrm{H}-1,55-56$ & 0.55 & - & + & - \\
\hline $1 \mathrm{H}-1,57-58$ & 0.57 & - & + & - \\
\hline $1 \mathrm{H}-1,58-59$ & 0.58 & TR & + & - \\
\hline $1 \mathrm{H}-1,60-61$ & 0.60 & - & + & - \\
\hline $1 \mathrm{H}-1,61-62$ & 0.61 & - & + & - \\
\hline $1 \mathrm{H}-1,62-63$ & 0.62 & - & + & - \\
\hline $1 \mathrm{H}-1,63-64$ & 0.63 & - & + & - \\
\hline $1 \mathrm{H}-1,64-65$ & 0.64 & - & + & - \\
\hline $1 \mathrm{H}-1,66-67$ & 0.66 & $\overline{\mathrm{TR}}$ & + & - \\
\hline $1 \mathrm{H}-1,69-70$ & 0.69 & TR & + & - \\
\hline $1 \mathrm{H}-1,74-75$ & 0.74 & $\mathrm{TR}$ & + & - \\
\hline $1 \mathrm{H}-1,78-79$ & 0.78 & - & + & - \\
\hline $1 \mathrm{H}-1,82-83$ & 0.82 & - & + & - \\
\hline $1 \mathrm{H}-1,87-89$ & 0.87 & - & - & - \\
\hline $1 \mathrm{H}-1,97-99$ & 0.97 & - & - & - \\
\hline $1 \mathrm{H}-1,115-117$ & 1.15 & - & + & - \\
\hline $1 \mathrm{H}-1,145-147$ & 1.45 & - & + & - \\
\hline $1 \mathrm{H}-2,50-52$ & 2.00 & - & + & - \\
\hline $1 \mathrm{H}-2,109-111$ & 2.59 & - & + & - \\
\hline $1 \mathrm{H}-2,139-141$ & 2.89 & - & + & - \\
\hline $1 \mathrm{H}-3,50-52$ & 3.50 & - & + & - \\
\hline $1 \mathrm{H}-3,90-92$ & 3.90 & TR & + & - \\
\hline $2 \mathrm{H}-1,50-55$ & 4.80 & - & - & - \\
\hline $2 \mathrm{H}-1,98-103$ & 5.28 & - & - & - \\
\hline $2 \mathrm{H}-2,50-55$ & 6.30 & - & - & - \\
\hline $2 \mathrm{H}-2,98-103$ & 6.78 & - & - & - \\
\hline $2 \mathrm{H}-3,50-55$ & 7.80 & - & - & - \\
\hline $2 \mathrm{H}-3,98-103$ & 8.28 & - & - & - \\
\hline $2 \mathrm{H}-4,50-55$ & 9.30 & - & - & - \\
\hline $2 \mathrm{H}-4,98-103$ & 9.78 & - & - & - \\
\hline $2 \mathrm{H}-5,50-55$ & 10.80 & - & + & - \\
\hline $2 \mathrm{H}-5,98-103$ & 11.82 & - & - & - \\
\hline $2 \mathrm{H}-6,50-55$ & 12.30 & - & + & 二 \\
\hline $2 \mathrm{H}-6,98-103$ & 12.78 & - & - & - \\
\hline $2 \mathrm{H}-7,10-14$ & 13.40 & - & - & - \\
\hline \multicolumn{5}{|l|}{$155-942 \mathrm{~A}-$} \\
\hline $4 \mathrm{H}-2,44-48$ & 24.77 & - & - & - \\
\hline $4 \mathrm{H}-4,81-82$ & 25.11 & TR & 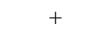 & 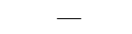 \\
\hline $4 \mathrm{H}-4,123-124$ & 25.53 & - & 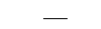 & - \\
\hline $4 \mathrm{H}-6,44-48$ & 30.77 & - & - & 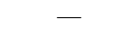 \\
\hline $5 \mathrm{H}-3,34-35$ & 35.65 & - & - & - \\
\hline $5 \mathrm{H}-4,22-23$ & 36.76 & - & - & - \\
\hline
\end{tabular}

\begin{tabular}{|c|c|c|c|c|}
\hline $\begin{array}{l}\text { Core, section, } \\
\text { interval }(\mathrm{cm})\end{array}$ & $\begin{array}{l}\text { Depth } \\
\text { (mbsf) }\end{array}$ & $\begin{array}{c}\text { Diatom } \\
\text { abundance }\end{array}$ & Spicules & Radiolarians \\
\hline $5 \mathrm{H}-6,104-109$ & 37.58 & - & - & - \\
\hline $5 \mathrm{H}-7,13-14$ & 40.22 & - & - & - \\
\hline $5 \mathrm{H}-7,30-35$ & 40.39 & - & - & - \\
\hline $5 \mathrm{H}-7,68-69$ & 40.77 & - & - & - \\
\hline $7 \mathrm{H}-1,121-122$ & 52.51 & - & - & - \\
\hline $7 \mathrm{H}-2,144-149$ & 52.64 & - & - & - \\
\hline $7 \mathrm{H}-4,63-68$ & 56.43 & - & - & - \\
\hline $8 \mathrm{H}-4,19-20$ & 65.49 & - & - & - \\
\hline $8 \mathrm{H}-4,59-60$ & 65.89 & - & - & - \\
\hline $8 \mathrm{H}-6,129-130$ & 66.59 & - & - & - \\
\hline \multicolumn{5}{|l|}{ 155-931A- } \\
\hline $1 \mathrm{H}-1, \mathrm{ML}$ & 0.0 & $\mathrm{C}$ & + & - \\
\hline $1 \mathrm{H}-1,0-1$ & 0.0 & TR & + & + \\
\hline $1 \mathrm{H}-1,5-6$ & 0.05 & $\mathrm{R}$ & + & + \\
\hline $1 \mathrm{H}-1,9-10$ & 0.09 & & + & + \\
\hline $1 \mathrm{H}-1,13-14$ & 0.13 & TR & + & + \\
\hline $1 \mathrm{H}-1,19-20$ & 0.19 & - & + & - \\
\hline $1 \mathrm{H}-1,26-27$ & 0.26 & - & + & + \\
\hline $1 \mathrm{H}-1,29-30$ & 0.29 & - & + & - \\
\hline $1 \mathrm{H}-1,34-35$ & 0.34 & - & + & - \\
\hline $1 \mathrm{H}-1,41-42$ & 0.41 & - & + & - \\
\hline $1 \mathrm{H}-1,45-46$ & 0.45 & - & + & - \\
\hline $1 \mathrm{H}-1,49-50$ & 0.49 & - & + & - \\
\hline $1 \mathrm{H}-1,51-52$ & 0.51 & - & + & - \\
\hline $1 \mathrm{H}-1,54-55$ & 0.54 & - & - & - \\
\hline $1 \mathrm{H}-1,58-59$ & 0.58 & - & - & - \\
\hline $1 \mathrm{H}-1,66-67$ & 0.66 & 二 & 二 & - \\
\hline $1 \mathrm{H}-1,69-70$ & 0.69 & - & - & - \\
\hline $1 \mathrm{H}-1,73-74$ & 0.73 & - & - & - \\
\hline $1 \mathrm{H}-1,84-85$ & 0.84 & - & - & - \\
\hline $1 \mathrm{H}-\mathrm{CC}$ & 6.14 & - & - & - \\
\hline $2 \mathrm{H}-\mathrm{CC}$ & 16.29 & - & + & - \\
\hline $3 \mathrm{H}-\mathrm{CC}$ & 25.83 & - & + & - \\
\hline \multicolumn{5}{|l|}{ 154-927B- } \\
\hline $1 \mathrm{H}-1,1-3$ & 0.02 & TR & + & - \\
\hline $1 \mathrm{H}-1,50-52$ & 0.51 & - & + & - \\
\hline $1 \mathrm{H}-1,120-122$ & 1.21 & - & - & - \\
\hline $1 \mathrm{H}-2,70-72$ & 2.21 & - & - & - \\
\hline $1 \mathrm{H}-2,127-129$ & 3.08 & - & - & - \\
\hline \multicolumn{5}{|l|}{ 154-927A- } \\
\hline $1 \mathrm{H}-3,7-9$ & 3.39 & - & - & - \\
\hline $1 \mathrm{H}-3,31-39$ & 3.69 & - & - & - \\
\hline $1 \mathrm{H}-3,87-89$ & 4.19 & - & - & - \\
\hline $1 \mathrm{H}-4,17-19$ & 4.99 & - & - & - \\
\hline $1 \mathrm{H}-4,67-69$ & 5.49 & - & - & - \\
\hline $1 \mathrm{H}-4,117-119$ & 5.99 & - & - & - \\
\hline \multicolumn{5}{|l|}{ 154-927B- } \\
\hline $2 \mathrm{H}-1,63-65$ & 6.05 & - & - & - \\
\hline $2 \mathrm{H}-1,73-75$ & 6.15 & - & - & - \\
\hline $2 \mathrm{H}-2,33-35$ & 7.25 & - & - & - \\
\hline $2 \mathrm{H}-2,103-105$ & 7.95 & - & - & - \\
\hline $2 \mathrm{H}-2,133-135$ & 8.25 & - & - & - \\
\hline $2 \mathrm{H}-3,63-65$ & 9.05 & - & - & - \\
\hline $2 \mathrm{H}-3,103-105$ & 9.45 & - & - & - \\
\hline $2 \mathrm{H}-3,133-135$ & 9.75 & - & - & - \\
\hline $2 \mathrm{H}-4,13-15$ & 10.05 & - & - & - \\
\hline $2 \mathrm{H}-4,33-35$ & 10.25 & - & - & - \\
\hline
\end{tabular}

Notes: The top of Hole $942 \mathrm{C}$ is recorded at $0.19 \mathrm{mbsf}$ due to a section misplaced during drilling operations. Diatom abundance: $=$ absent; $\mathrm{TR}=\operatorname{trace}(<1 \%) ; \mathrm{R}=\operatorname{rare}(<5 \%) ; \mathrm{F}=$ few $(5 \%-$ $30 \%) ; \mathrm{C}=$ common $(30 \%-60 \%) ;$ and $\mathrm{A}=$ abundant $(>60 \%)$. Radiolarian and sponge spicule occurance: $+=$ present; $-=$ absent.

within the Younger Dryas event at the transition to the glacial sediments. Diatoms are absent from the glacial deposits with the exception of a few highly corroded valves in glacial turbidites where siliceous sponge spicules also occur. Contrary to the Holocene interglacial, diatoms are absent from the expanded interglacial Eemian section of Site 942 (Showers et al., this volume), except for a few fragments in one sample (Table 1).

This pattern is similar to that found in the open ocean environment of the Ceara Rise region (Site 927, Fig. 1). At Site 927, diatoms are present only in the Holocene section and are absent from the sections representing isotope Stages 2-4 (Table 2). In the Ceara Rise region, diatoms reappear in sediments of pre-Quaternary age (Mikkelsen and Barron, in press). Sediments of these ages were not recovered from the Amazon Fan.

\section{Other Siliceous Microfossils}

Radiolarians and siliceous sponge spicules are more solution resistant than diatoms (Schrader, 1972), and they are found in many of the Amazon Fan sections that are barren of diatoms. Siliceous sponge spicules in particular are consistently present in glacial intervals, although in low abundances. The siliceous spicules are all microscleres 

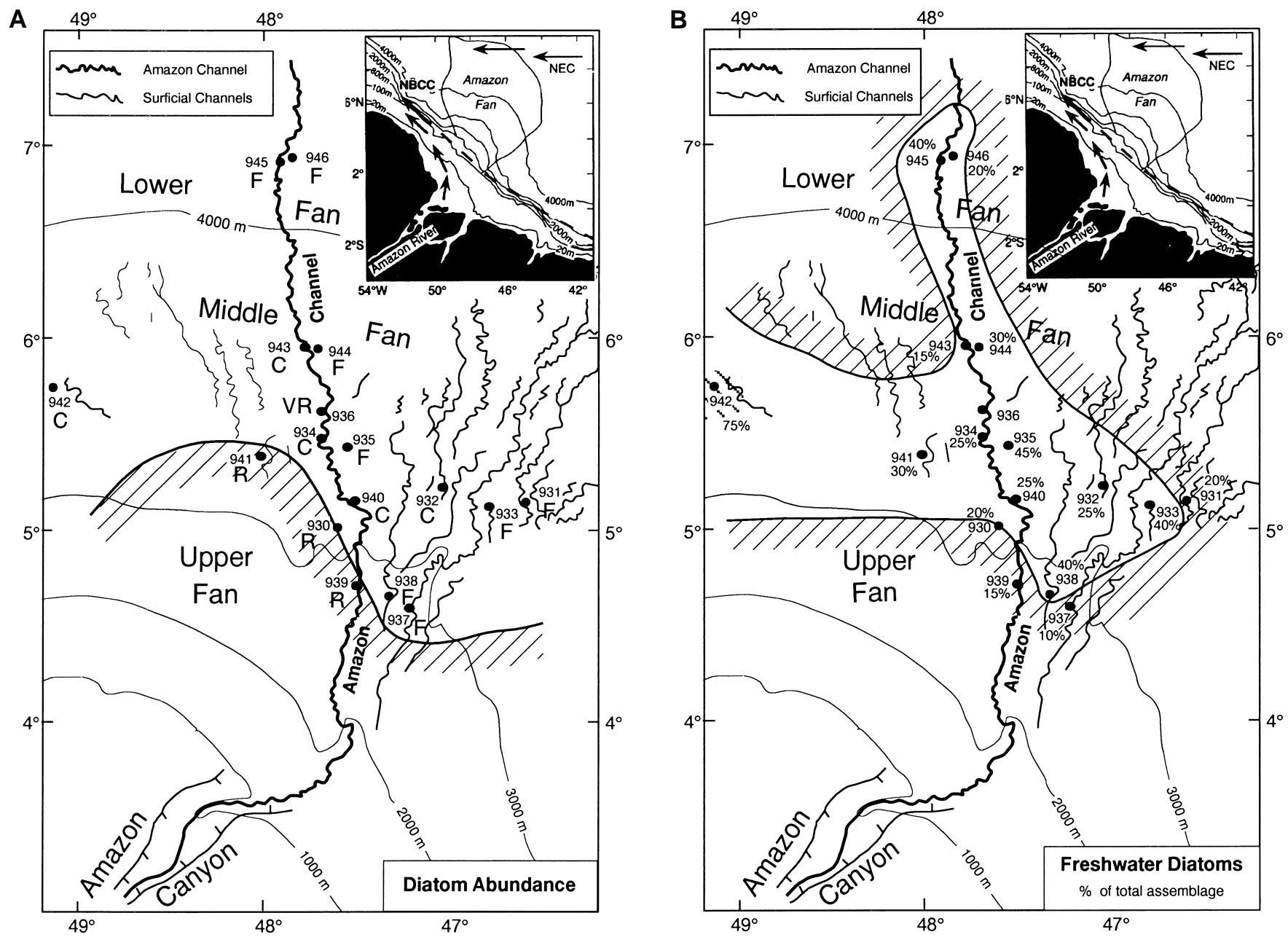

Figure 2. A. Generalized abundance distribution of diatoms in the surface sediments of Leg 155 sites $(C=$ common, $F=$ few, $R=$ rare, and VR $=$ very rare $)$. B. The relative abundance of freshwater diatoms (in percent) of the total assemblage. Depth contours are in meters below sea surface. Inserted is a sketch map (from Showers and Bevis, 1988) with present-day surface circulation during peak discharge of the Amazon River (NEC = North Equatorial Current).

$(10-100 \mu \mathrm{M})$ and are hollow along an axial channel. White nodules ranging in diameter from 1 to $5 \mathrm{~mm}$ are also present in several cores (e.g., Sample 155-938A-28X-CC, 3-13 cm). These clusters contain abundant sponge spicules, and may be individual small sponges or parts of larger sponges similar to those reported from the Quaternary sediments off Peru (Martini and Locker, 1990).

\section{DISCUSSION}

The world oceans are undersaturated with silica (Broecker and Peng, 1982; Tréguer et al., 1995), and therefore most of the siliceous microfossil tests produced in the photic zone dissolve before reaching the seafloor. The amount of siliceous microfossils preserved in the surface sediments is, on a gross scale, proportional with the opal rain rate (Broecker and Peng, 1982). Even though buried siliceous tests may provide a qualitative record of opal production through time, opal flux to the seafloor is not always a true productivity indicator due to distortion of the original signal, for example, by changes in bottom-water chemical compositions, post-burial processes, changes in sedimentation rates, and depositional patterns (Archer et al., 1993; Bareille et al., 1991; Lyle et al., 1988; Rea et al., 1991; Verardo and McIntyre, 1994).

The depositional environment of the Amazon Fan region changed significantly between glacial and interglacial modes. During glacial periods the drop in sea level transformed the shelf area into marsh land (Haberle, this volume) that was intersected by the Amazon Canyon. The canyon funneled river-borne sediments from the South American continent directly onto the deep-sea fan (Damuth and $\mathrm{Ku}$ mar, 1975). The glacial sediments are devoid of diatoms, although Edmond et al. (1981) speculated that biogenic detritus, including diatoms, would be transported through the Amazon River canyon during low sea-level stands to the deep sea. During high sea-level stands, deposition on the Amazon Fan is characterized by normal oceanic sedimentation, and hemipelagic interglacial carbonate oozes are recorded in a number of sites and interbedded with glacial deposits (Flood and Piper, this volume; Maslin and Mikkelsen, this volume).

The fact that diatoms are common only in the surface sediments, decrease rapidly in abundance in the underlying Holocene and upper Pleistocene sediments, and are virtually lacking in the Eemian interglacial sediments, is likely a reflection of post-depositional dissolution. The pore-water silica concentrations in the upper few meters of the Amazon Fan are generally greater than $300 \mu \mathrm{M} / \mathrm{L}$ (Flood, Piper, Klaus, et al., 1995), and thus high compared with the average concentrations of oceanic bottom waters (average 30-40 $\mu \mathrm{M} / \mathrm{L}$; Broecker and Peng, 1982). This high silica value points to post-burial dissolution of the diatoms and diffusion of dissolved silica out of the sediments. Furthermore, the abundance and preservation of calcareous nannofossils and foraminifers indicate similar productivity patterns in the Holocene and Eemian in the Amazon Fan area (Maslin and 
Table 2. Marine planktonic, benthic, and freshwater diatoms recorded in the Amazon drill sites.

\begin{tabular}{l} 
Marine species \\
\hline Actinocyclus curvatulus $\mathrm{C}$ \\
Asteromphalus elegans $\mathrm{R}$ \\
Azpeitia nodulifera $\mathrm{C}$ \\
Azpeitia tabularis $\mathrm{C}$ \\
Chaetoceros sp. $\mathrm{R}$ \\
Coscinodiscus africanus $\mathrm{R}$ \\
Coscinodiscus curvatulus $\mathrm{R}$ \\
Hemidiscus cuneiformis $\mathrm{R}$ \\
Pseudoeunotia doliolus $\mathrm{R}$ \\
Nitzschia marina $\mathrm{R}$ \\
Rhizosolenia bergonii $\mathrm{R}$ \\
Roperia tessellata $\mathrm{R}$ \\
Thalassiosira eccentrica $\mathrm{R}$ \\
Thalassiothrix longissima $\mathrm{R}$ \\
Thalassionema nitzschioides $\mathrm{R}$ \\
Thalassionema nitzschioides var. parva $\mathrm{C}$ \\
Thalassiosira oestrupii $\mathrm{C}$ \\
\hline \multicolumn{1}{c}{ Freshwater species } \\
\hline Aulacosira granulata $\mathrm{C}$ \\
Aulacosira sulcata $\mathrm{C}$ \\
Cyclotella litoralis $\mathrm{R}$ \\
Cyclotella striata $\mathrm{C}$ \\
\hline \multicolumn{1}{c}{ Benthic diatoms } \\
\hline Biddulphia sp. $\mathrm{R}$ \\
Cocconeis sp. $\mathrm{R}$ \\
Diploneis sp. $\mathrm{R}$ \\
Hemiaulus sp. $\mathrm{R}$ \\
Navicula sp. $\mathrm{R}$ \\
Triceratium sp. $\mathrm{R}$ \\
\hline
\end{tabular}

Note: The relative abundance is recorded as $\mathrm{C}=$ common and $\mathrm{R}=$ rare.

Mikkelsen, this volume). Thus, the lack of Eemian diatoms is likely due to post-depositional dissolution rather than to any significant difference in productivity between the Holocene and the Eemian.

There is a notable difference in the abundance of upper Quaternary diatoms in the sedimentary records of the eastern and the western equatorial Atlantic. Whereas diatoms are rare in the upper Pleistocene/Holocene sections of the Amazon Fan and the Ceara Rise in the western equatorial Atlantic, diatoms are generally abundant and well preserved in the eastern equatorial Atlantic (Baldauf and Pokras, 1989; Mikkelsen, 1984; Stabell, 1986; Van Iperen et al., 1987). In the eastern Atlantic, diatom productivity fluctuates greatly, between high productivity during glacial stages $(2,4$, and $5 / 6$ boundary) and low during interglacial stages (especially $5 \mathrm{~d}, 5 \mathrm{e}$, and the middle of isotope Stage 1; Pokras, 1987). The lower productivity recorded in the eastern Atlantic in the middle of isotope Stage 1 (Pokras, 1987) is also recognized by a lower diatom abundance (Fig. 2). As in the Amazon Fan deposits, this abundance decrease mirrors a drop in planktonic $\delta^{13} \mathrm{C}$ values in piston cores from the Amazon Fan (R. Schneider, pers. comm., 1994); the decrease is likely a result of a short-lived decrease in available nutrients and productivity.

Considering the high abundance of diatoms in glacial-aged sediments in the eastern equatorial Atlantic, the lack of diatoms in glacial-aged Amazon Fan sediments is probably not the result of a reduced glacial productivity, but rather is controlled by the overall lower productivity in the western Atlantic. A contributing factor may be dilution caused by the extremely high glacial sedimentation rates (average $50 \mathrm{~m} / 1000 \mathrm{yr}$ during glacials vs. $5-10 \mathrm{~cm} / 1000 \mathrm{yr}$ during interglacials). In the Ceara Rise region, sedimentation rates did not change significantly between glacial and interglacial modes (Curry, Shackleton, Richter, et al., 1995). In the Ceara region, the lack of diatoms in glacial sediments seems also to be controlled by post-depositional dissolution superimposed by the generally low productivity in the nutrient-depleted waters of the western tropical Atlantic (Fig. 4).

\section{CONCLUSION}

Diatoms are generally rare in the upper Quaternary sediments recovered from Leg 155 sites on the Amazon Fan. The diatom assemblages are characterized by a low abundance of dominantly solutionresistant species of marine origin with a minor contribution (average $10 \%-30 \%$ ) of freshwater diatoms transported to the Amazon Fan by the freshwater plume of the Amazon River. The highest abundance of freshwater diatoms is found in a site off the fan, which is likely a result of a deflection of the Amazon freshwater plume.

The overall difference between the abundant and well-preserved upper Quaternary diatoms in the eastern equatorial Atlantic and the rare and poorly preserved diatoms of the Amazon Fan and the Ceara Rise region in the western equatorial Atlantic is controlled by preservation and dilution by terrigenous sediments during glacial periods superimposed on the cross-basinal productivity gradient in the tropical Atlantic Ocean.

\section{ACKNOWLEDGMENTS}

Bill Curry and Jim Cullen kindly provided samples from the Ceara Rise for this preliminary investigation, Birgit Jørgensen cheerful technical assistance, and John Barron friendly and never failing advice. Teasing comments at sea from shipboard fellows were appreciated during the tedious search for the rarely occurring diatoms. Appreciated also are reviews by Lloyd Burckle, Larry Peterson, and an anonymous reviewer. The Danish Natural Science Research Council financed the cruise participation.

\section{REFERENCES}

Archer, D., Lyle, M., Rodgers, K., and Froelich, P., 1993. What controls opal preservation in tropical deep-sea sediments? Paleoceanography, 8:7-21.

Baldauf, J.G., and Pokras, E.M., 1989. Diatom biostratigraphy of Leg 108 sediments: eastern tropical Atlantic Ocean. In Ruddiman, W., Sarnthein, M., et al., Proc. ODP, Sci. Results, 108: College Station, TX (Ocean Drilling Program), 23-34.

Bareille, G., Labracherie, M., Labeyrie, L., Pichon, J.-J., and Turon, J.-L., 1991. Biogenic silica accumulation rates during the Holocene in the southeastern Indian Ocean. Mar. Chem., 35:537-551.

Barron, J.A., 1985. Late Eocene to Holocene diatom biostratigraphy of the equatorial Pacific Ocean, Deep Sea Drilling Project Leg 85. In Mayer, L., Theyer, F., Thomas, E., et al., Init. Repts. DSDP, 85: Washington (U.S. Govt. Printing Office), 413-456.

Broecker, W.S., and Peng, T.-H., 1982. Tracers in the Sea: Palisades, NY (Lamont-Doherty Geol. Observ.).

Curry, W.B., Shackleton, N.J., Richter, C., et al., 1995. Proc. ODP, Init. Repts., 154: College Station, TX (Ocean Drilling Program).

Damuth, J.E., and Kumar, N., 1975. Amazon Cone: morphology, sediments, age, and growth pattern. Geol. Soc. Am. Bull., 86:863-878.

DeMaster, D.J., Knapp, G.B., and Nittrouer, C.A., 1983. Biological uptake and accumulation of silica on the Amazon continental shelf. Geochim. Cosmochim. Acta, 47:1713-1723.

Edmond, J.M., Boyle, E.A., Grant, B., and Stallard, R.F., 1981. The chemical mass balance in the Amazon plume I: the nutrients. Deep-Sea Res. Part A, 28:1339-1374.

Flood, R.D., Piper, D.J.W., Klaus, A., et al., 1995. Proc. ODP, Init. Repts., 155: College Station, TX (Ocean Drilling Program).

Gasse, F., Stabell, B., Fourtanier, E., and van Iperen, Y., 1989. Freshwater diatom influx in intertropical Atlantic: relationships with continental records from Africa. Quat. Res., 32:229-243.

Gessner, F., and Simonsen, R., 1967. Marine diatoms in the Amazon. Limnol. Oceanogr., 12:709-711.

Lisitzin, A.P., 1972. Sedimentation in the world ocean. Spec. Publ.-Soc. Econ. Paleontol. Mineral., 17:81-88.

Lyle, M., Murray, D.W., Finney, B.P., Dymond, J., Robbins, J.M., and Brooksforce, K., 1988. The record of Late Pleistocene biogenic sedimentation in the eastern tropical Pacific Ocean. Paleoceanography, 3:39-59. 
Martini, E., and Locker, S., 1990. Clusters of sponge spicules from Quaternary sediments at Sites 685 and 688 off Peru. In Suess, E., von Huene, R., et al., Proc. ODP, Sci. Results, 112: College Station, TX (Ocean Drilling Program), 175-180.

Mikkelsen, N., 1984. Diatoms in the Zaire deep-sea fan and Pleistocene palaeoclimatic trends in the Angola Basin and west equatorial Africa. Neth. J. Sea Res., 17:280-292.

Mikkelsen, N., and Barron, J., in press. Early Oligocene diatoms on the Ceara Rise and the Cenozoic evolution of biogenic silica accumulation in the low-latitude Atlantic. In Shackleton, N.J., Curry, W.B., Richter, C., and Bralower, T.J. (Eds.), Proc. ODP, Sci. Results, 154: College Station, TX (Ocean Drilling Program).

Milliman, J.D., and Boyle, E., 1975. Biological uptake of dissolved silica in the Amazon River estuary. Science, 189:995-997.

Pokras, E.M., 1987. Diatom record of Late Quaternary climatic change in the eastern equatorial Atlantic and tropical Africa. Paleoceanography, 2:273-286.

Pokras, E.M., and Ruddiman, W.F., 1989. Evolution of South Saharan/Sahelian aridity based on freshwater diatoms (genus Melosira) and opal phytoliths: Sites 662 and 664. In Ruddiman, W., Sarnthein, M., et al., Proc. ODP, Sci. Results, 108: College Station, TX (Ocean Drilling Program), 143-148.

Rea, D.K., Pisias, N.G., and Newberry, T., 1991. Late Pleistocene paleoclimatology of the central Equatorial Pacific: flux patterns of biogenic sediments. Paleoceanography, 6:227-244.

Schrader, H.-J., 1972. Kieselsaure-Skelette in sedimenten des ibero-marokkanischen Kontinentalrandes und angrendzender Tiefsee Ebenen. “Meteor” Forschungsergeb. Reihe C, 8:10-36.
Showers, W.J., and Bevis, M., 1988. Amazon Cone isotopic stratigraphy: evidence for the source of the tropical meltwater spike. Palaeogeogr., Palaeoclimatol., Palaeoecol., 64:189-199.

Stabell, B., 1986. Variations of diatom flux in the eastern equatorial Atlantic during the last 400,000 years ("Meteor" cores 13519 and 13521). Mar. Geol., 72:305-323.

Tréguer, P., Nelson, D.M., Van Bennekom, A.J., DeMaster, D.J., Leynaert, A., and Quéguiner, B., 1995. The silica balance in the world ocean: a reestimate. Science, 268:375-379.

Van Iperen, J.M., van Weering, T.C.E., Jansen, J.H.F., and van Bennekom, A.J., 1987. Diatoms in surface sediments of the Zaire deep-sea fan (SE Atlantic Ocean) and their relation to overlying water masses. Neth. J. Sea Res., 21:203-217.

Verardo, C.D.J., and McIntyre, A., 1994. Production and destruction: control of biogenous sedimentation in the tropical Atlantic 0-300,000 years B.P. Paleoceanography, 9:63-86.

Wood, E.J.F., 1966. A phytoplankton study of the Amazon region. Bull. Mar. Sci., 16:102-123.

Date of initial receipt: 29 November 1995

Date of acceptance: 6 June 1996

Ms 155SR-218
Figure 3. Downcore variation in the abundance of diatoms in Holes 942C and 931A (from the Amazon Fan). Isotope stratigraphy is inferred from Hole 942A (Showers et al., this volume). Showers and Bevis (1988) have dated the Iron Pan Crust to $9.3 \mathrm{ka}$ in the central Amazon Fan region.

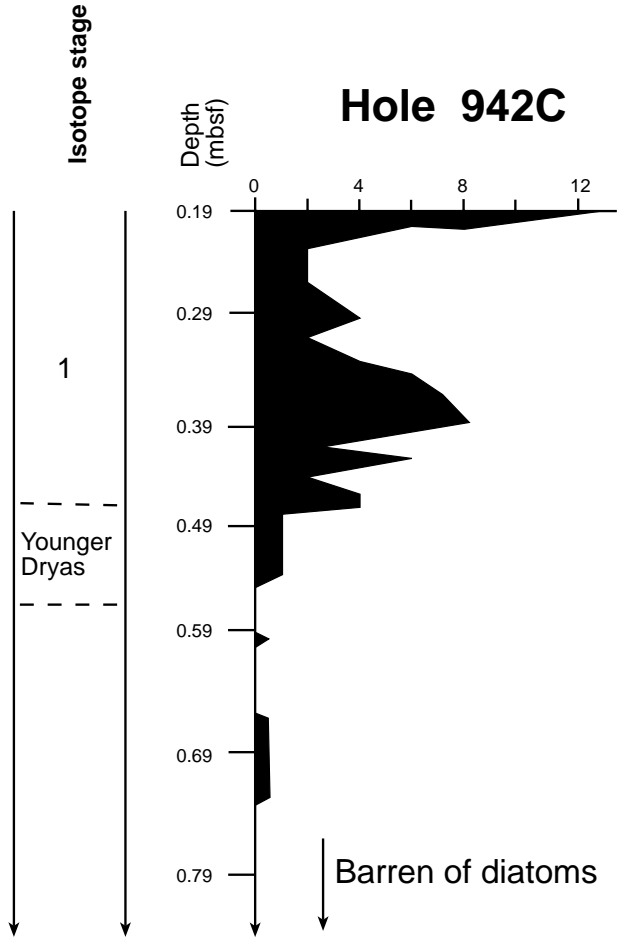




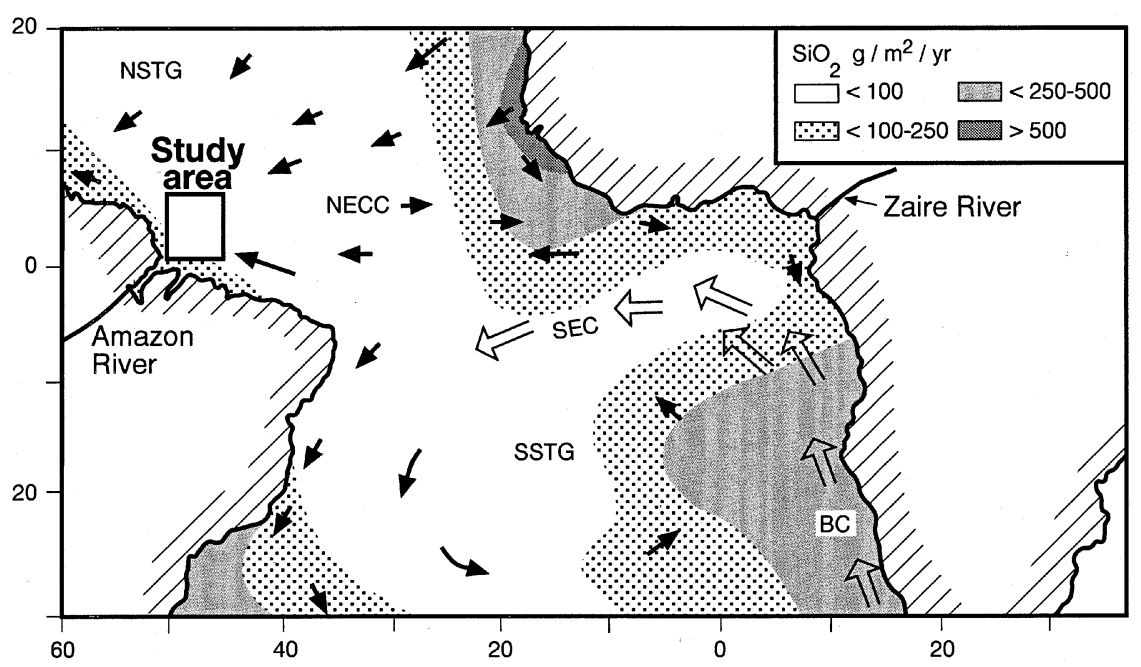

Figure 4. Surface ocean circulation of the tropical Atlantic (modified from Pokras, 1987). Sizes of arrows are proportional to the intensity of circulation. BC $=$ Benguela Current; NECC $=$ North Equatorial Counter Current; NSTG = North Subtropical Gyre; SEC = South Equatorial Current; SSTG = South Subtropical Gyre. Data on the biogenic silica production (in grams per square meter per year ) are from Lisitzin (1972). 